\title{
Aleksandra Nalewaj
}

\section{Janowe wyznania wiary w ujęciu Prospera Grecha}

Tradycja Janowa przechowuje wiele tekstów, które przez swoją strukturę literacką i zawartość teologiczną jednoznacznie wskazują na treść wyznania wiary. Prosper Grech ${ }^{1}$, korzystając z wyników badań m.in. J. Gnilki, W. Kramera, J. L. Martyna, V. H. Neufelda i G. Segalli dokonał wyboru tekstów wyznań w czwartej Ewangelii i Listach Jana oraz ich klasyfikacji². W syntetycznym opracowaniu autor charakteryzuje najpierw homologie w Nowym Testamencie, by następnie zarysować problem wyznań wiary w Corpus Joanneum.

\section{Nowotestamentalne wyznania wiary w ogólności}

Zdaniem Grecha wyznania wiary Nowego Testamentu streszczone w zwięzłej formule stanowią odpowiedź wspólnoty lub jednostki na apostolskie głoszenie Chrystusa i tego, co On znaczy dla wierzących ${ }^{3}$. Podczas gdy podmiot (wyznający wiarę) występuje w pierwszej osobie liczby pojedynczej lub mnogiej: ,ja wierze (my wierzymy)”, przedmiot wyznania pozostaje w drugiej lub trzeciej osobie liczby pojedynczej: „że Ty (On) jesteś (jest) Chrystusem”.

Wyznania wiary pierwotnych gmin chrześcijańskich autor dzieli na pięć grup, przy czym w każdej grupie występują po dwa rodzaje wyznań, a mianowicie aklamacje i formuły wiary:

- formuły nominalne i werbalne,

${ }^{1}$ Le confessioni di fede in Giovanni, [w:] Atti del VI Simposio di Efeso su S. Giovanni apostolo, a cura di L. Padovese, Roma 1996, 29-36 (Turchia, la Chiesa e la sua storia, 11).

${ }^{2} \mathrm{Z}$ polskich uczonych temat wyznań wiary w Corpus Joanneum podejmują m.in. J. CHMIEL, Czy Pierwszy List św. Jana jest rozbudowana homilia chrzcielną?, RBL 26 (1973), 1-2; H. LANGKAMMER, Credo najstarszych społeczności chrześcijańskich jako odpowiedź na najstarszy kerygmat paschalny, [w:] Wprowadzenie do Ksiag Nowego Testamentu, Wrocław 1990, 88-117, zwłaszcza 98-100; S. Mędala, Chrystologia Ewangelii św. Jana, Kraków 1993, 103-193, E. SzYMANEK, Wiara i niewiara, [w:] Ewangelia św. Jana, Lublin 1992, 261-281.

${ }^{3}$ Wyrażenia: „wyznanie wiary” i „formuła wiary” P. Grech stosuje zamiennie. Inaczej zob. H. LangKammer, Credo najstarszych społeczności chrześcijańskich jako odpowiedź na najstarszy kerygmat paschalny, art. cyt., 89-97. 
- formuły proste i złożone,

- formuły pozytywne i negatywne,

- formuły pełne i częściowe.

Jako przykład aklamacji autor proponuje wyznanie: „zaprawdę, Ten jest Synem Bożym” (Mk 15, 39). Formułę wiary poprzedza czasownik wprowadzając wprost lub pośrednio w semantyczny wymiar wiary, np. ,ja wierzę, że Ty jesteś Chrystus" (J 11, 27).

W wyznaniach nominalnych przedmiot wiary występuje w podmiocie, „że Ty jesteś Chrystus”, zaś w formułach werbalnych nawiązujących do dzieła Zbawiciela kontemplowany pełni rolę orzeczenia, np. „że Chrystus umarł za nasze grzechy" (1 Kor 15, 3).

Wyznania proste zawierają jedną aklamację lub zdanie, zaś złożone kilka aklamacji lub zdań.

Do grupy wyznań pozytywnych autor zalicza formuły, które wskazują na treść wiary. Wyznania negatywne, z kolei, wprowadza zaprzeczenie, np. „Kto nie wyznaje, że Chrystus przyszedł w ciele” (2 J 7) lub wyznanie Jana Chrzciciela: „Ja nie jestem Chrystusem” (J 1, 20).

Ostatnią grupę wyznań stanowią wyznania pełne i częściowe. Pierwsze z nich wyrażają pełnię wiary Kościoła, drugie zaś - chociaż pozytywne - nie zawierają pełni wiary, ale podkreślają jej pewien aspekt. Jako przykład wyznania częściowego komentator proponuje tekst J 6, 14, w którym lud galilejski uznaje w Jezusie Proroka, a nie Syna Bożego.

Odnośnie do Sitz im Leben formuł wiary pierwotnego Kościoła Prosper Grech $^{4}$ przypuszcza, że jest nim kult, a przede wszystkim liturgia chrzcielna. Uwzględniając złożoną sytuację chrześcijaństwa u schyłku I wieku, środowiskiem życiowym chrystologicznych wyznań mogły być spory z Żydami, poganami lub błędy rodzące się w łonie Kościoła. Formuły wyznań były najprawdopodobniej wygłaszane w sytuacji prześladowań lub jako odpowiedź na cuda Jezusa. Autor podkreśla, że niezależnie od tego, czy wypowiadającym homologię jest pojedyncza osoba czy wspólnota, jej prawdziwym autorem jest Duch Paraklet lub Bóg. Prawdę o boskim autorstwie wyznań potwierdza wiele tekstów Nowego Testamentu. Po wyznaniu Piotra pod Cezareą Filipową (por. Mt 16,16) Jezus wyjaśnia, że tę prawdę objawił apostołowi Bóg Ojciec (por. Mt 16, 17). Wobec trybunałów w imieniu skazanych będzie natomiast przemawiał sam Duch Święty (por. Mt 10, 18-20). Paweł Apostoł w 1 Kor 12, 3 stwierdza: „,nikt bez pomocy Ducha nie może powiedzieć: JEZUS JEST PANEM”, zaś tradycja Janowa zaświadcza, że źródłem wyznań jest Duch prorocki (por. 1 J 4, 2; Ap 19, 10).

\footnotetext{
${ }^{4}$ Por. Le confessioni di fede in Giovanni, art. cyt., 29-30.
} 
Podsumowując rozważania na temat wczesnochrześcijańskich formuł wiary komentator podkreśla, że ich treść będzie stanowić w przyszłości credo Kościoła, czyli ostateczne kryterium ortodoksji. Kryterium prawdziwości wyznań i formuł wiary jest bowiem ich zgodność lub niezgodność z pierwotnym przepowiadaniem apostolskim.

\section{Homologie w czwartej Ewangelii i 1-2 J}

W pismach Janowych Grech wyróżnia 32 grupy tekstów, które w ścisłym sensie można nazwać wyznaniami wiary, a mianowicie:

1) J 1, 20-21; 3, 28; 2) J 1, 29; 1, 36; 3) J 1, 32-34; 4) 1, 41; 5) J 1, 45; 6) J 1, 49; 7) J 2, 11; 2, 23; 10, 41; 8) J 3, 2; 9) J 4, 19; 10) J 4, 29; 11) J 4, 42; 12) J 4, 53; 13) J 5, 15; 14) J 6,14 ; 15) J 6 , 69; 16) J 7, 40-41; 17) J 9, 17; 18) $\mathrm{J} 9$, 22; 19) J 9, 35-38; 20) J 11, 27; 21) J 11, 45; 22) J 12, 13; 23) J 16, 30; 24) J 20, 28; 25) J 21, 7; 26) 1 J 2, 22-23; 27) 1 J 4, 2; 28) 1 J 4, 14-15; 29) $1 \mathrm{~J} 5,1$; 30) $1 \mathrm{~J} 5,5 ; 1 \mathrm{~J} 5,10$; 31) $1 \mathrm{~J} 5,20$; 32) 2 J 7.

Stosując kryteria przyjęte wcześniej do klasyfikacji homologii w Nowym Testamencie, autor ${ }^{5}$ dzieli Janowe wyznania następująco:

- 7 aklamacji i 10 formuł wiary,

- 21 formuł nominalnych i 5 formuł werbalnych,

- 15 formuł prostych i 11 formuł złożonych,

- 24 formuły pozytywne i 4 formuły negatywne,

- 5 formuł częściowych.

Jak widać, jedno wyznanie może spełniać kilka kryteriów, to znaczy może być zarówno aklamacją, wyznaniem prostym i pozytywnym lub na przykład częściowym i nominalnym.

Pomimo ubogiego języka czwartej Ewangelii komentator ${ }^{6}$ zwraca uwagę na bogactwo tytułów chrystologicznych, które są istotą nominalnych wyznań wiary, a mianowicie:

- Chrystus - J 1, 20-21; 3, 28; 7, 40-41; 9, 22; 11, 27; 1 J 2, 22-23; 1 J 5, 1;

- Prorok - J 1, 20-21; 4, 19; 6, 14; 7, 40-41; 9, 17;

- Baranek Boży - J 1, 29. 36;

- Mesjasz - J 1, 41;

- (Ten), o którym napisat Mojżesz - J 1, 45;

- Król Izraela - J 1, 49; 12, 13;

- Rabbi- J 3, 2;

- Zbawiciel świata - J 4, 42;

- Syn Człowieczy - J 9, 35-38;

${ }^{5}$ Por. Le confessioni di fede in Giovanni, art. cyt., 34.

${ }^{6}$ Por. tamże, 34-35. 
- Pan - J 20, 28; 21, 7;

- Bóg - J 20, 28;

$-z \operatorname{Bog} a-1 \mathrm{~J} 4,2$

- Syn Boży - J 1, 32-34; 1, 49; 11, 27; 1 J 4, 14-15.

Dla wyznań werbalnych charakterystyczne są następujące wyrażenia:

- bierze grzech - J 1, 29;

- zanurza w Duchu - J 1, 32-34;

- od Boga przybyt - J 3, 2;

- od Boga wyszedt - J 16, 30;

- przybywa w imię Pańskie - J 12, 13;

- przybyly w ciele - $1 \mathrm{~J}$ 4, 2.

Janowe formuły wiary wprowadzają czasowniki, które w kontekście czwartego ewangelisty przyjmują znaczenie chrystologiczne. Są to następujące terminy:

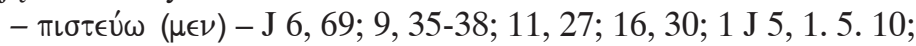

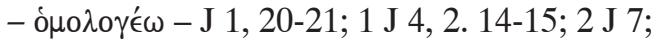

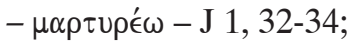

- oî̉ $\alpha(\mu \in \nu)$ - J 3, 2; 4, 42; 16, 30; 1 J 5, 20;

- $\gamma\llcorner\nu \omega \sigma \sigma \kappa \omega(\mu \in \nu)-\mathrm{J}$ 6, 69; 1 J 4, 6;

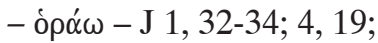

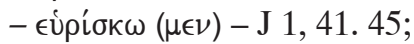

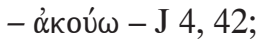

- $\theta \epsilon \alpha \dot{O} \mu \mu \alpha \mathrm{L}-\mathrm{J} 1,32$

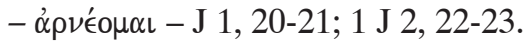

Co do klasyfikacji wyznań Janowych według ich Sitz im Leben, Prosper Grech podkreśla, że to rozróżnienie będzie tylko hipotetyczne z uwagi na liczne kontrowersje między egzegetami. Różnica zdań dotyczy zarówno okoliczności historycznych, jak i ewolucji wspólnoty Janowej. Autor proponuje następujący podział wyznań:

- jako odpowiedź na znaki Jezusa - J 6, 69,

- przeciw wyznawcom Jana Chrzciciela jako Mesjasza - J 1, 20-21; 3 , $28 ; 1,29 ; 1,36 ; 1,32-34$,

- przeciw Żydom - J 9, 17,

- przeciw kultowi imperatora - J 20, 28,

- przeciw judeochrześcijanom lub odstępcom - J 6, 69; 20, 28; 1 J 2, 22-23; 1 J 4, 14; 1 J 5, 1; 1 J 5, 5,

- przeciw początkowemu doketyzmowi - J 6, 69; 12, 13; 2 J 7,

- przeciw Żydom niezdecydowanym - J 3, 2.

W konkluzji Grech podkreśla, że pisma Janowe nie zawierają wyznań ekspiacyjnych, tak charakterystycznych dla Listów Pawła i Dziejów Apostolskich. 
Zdaniem komentatora, jest to wynik zamierzonego działania Jana, którego Ewangelia stanowi świadectwo o Chrystusie ujęte w ramy odgórnej chrystologii. Fakty dotyczące męki i śmierci Jezusa, Jego zmartwychwstania i wniebowstąpienia były jednak znane ewangeliście, co wynika z wielu tekstów. Na początku narracji czwartej Ewangelii Jezus pojawia się jako Baranek ofiarny (por. 1, 29.36), a tytuł „Kyrios” występuje dopiero po Jego zmartwychwstaniu. Tytuły chrystologiczne wraz z biegiem wydarzeń stają się coraz mocniejsze, by osiągnąć punkt kulminacyjny w wyznaniu Tomasza (por. J 20, 28).

Według autora, nie wszystkie wyznania przekazane przez tradycję Janową były stosowane w liturgii. Wiele z nich posiada funkcję wyłącznie literacką i teologiczną. Z formuł, które jak można sądzić były używane w kulcie, Prosper Grech rekonstruuje następujące credo czwartego ewangelisty: Wierzę (wierzymy), że Jezus jest Chrystusem, Synem Bożym, Synem Człowieczym, Zbawicielem świata, który od Boga przyszedł, Bóg przybyły w ciele, by zgładzić grzech świata jako Baranek. On jest naszym Panem i Bogiem.

Grech w syntetycznym studium podaje wyniki badań nad Janowymi wyznaniami wiary. $Z$ uwagi na wąskie ramy opracowania wydaje się, że zamiarem autora było raczej zwrócenie uwagi na problem zawarty w temacie niż jego rozwiązanie. Komentator ogranicza się jedynie do wyboru 32 grup wyznań w czwartej Ewangelii i 1-2 J oraz ich klasyfikacji.

Uwzględniając wcześniejsze uwagi autora o strukturze wyznań wiary, pewną niekonsekwencją z jego strony wydaje się być zaliczenie niektórych tekstów do grupy homologii. Chodzi mianowicie o sumaria i komentarze ewangelisty świadczące o wierze, która jest rezultatem widzenia znaków uczynionych przez Jezusa. Teksty J 2, 23 i 10, 41 (także 5, 15) nie posiadają struktury charakterystycznej dla formuł wiary. Skoro jednak Prosper Grech zalicza wspomniane teksty do grupy wyznań to, postępując za jego tokiem myślowym, listę Janowych formuł należałoby wzbogacić tekstami o podobnym charakterze pominiętymi przez autora, a mianowicie: J 12, $10-11$. 17. 42 oraz 20,8 . Teksty z $\mathbf{J} 12$ są wypowiedzią narratora informującą o wierze w Jezusa po wskrzeszeniu Łazarza i mesjańskim ingresie do Jerozolimy. Natomiast J 20, 8 stanowi wymowne świadectwo ewangelisty o wierze umiłowanego ucznia, która rodzi się wobec doświadczenia pustego grobu. Czasownik $\pi\llcorner\sigma \tau \in \dot{\omega} \omega$ został użyty w tym miejscu w aoryście i bez dopełnienia, czyli w formie absolutnej. To oznacza, że wiara ucznia, jeszcze bez widzenia Zmartwychwstałego, jest definitywna.

Opracowanie Grecha na temat Janowych homologii zawiera trafne spostrzeżenia mogące stanowić punkt wyjścia do dalszych, owocnych badań we wskazanym kierunku. Cenną może się okazać zwłaszcza klasyfikacja wyznań dokonana w oparciu o następujące kryteria: 
- czasowniki wprowadzające wyznanie,

- tytuły chrystologiczne,

- dzieło zbawcze Jezusa,

- Sitz im Leben.

Istnienie tak dużej liczby formuł wiary w pismach Janowych świadczy o krystalizowaniu się doktryny chrystologicznej już u progu chrześcijaństwa.

Olsztyn

ALEKSANDRA NALEWAJ

Summary

John's confessions of faith according to Prosper Grech

Confessions of faith in the New Testament are the Early Church's reply to the apostolic kerygma, which centre was Jesus and His saving work. The John's Tradition includes many texts, which in their literature structure and theological content unmistakably indicate the confession of faith. In the Fourth Gospel and John's Epistels, Prosper Grech has distinguished thirty-two text groups, which can be called formulae of faith in strict sense. The author has classified the formulae according to the following criteria:

- verbs that introduce confessions,

- Christological titles,

- Jesus' work,

- Sitz im Leben of formulae.

The Johannine Tradition does not include the formulae on Jesus' Passion and Death which are so frequent in St. Paul and the Acts of the Apostles because the fourth evangelist represents the high Christology. His ideas are focusing on Incarnation, Revelation and Salvation with a universal dimension.

Presence of so many homologies in the Writings of John proves that in the Early Christian era the Christological ideas were developing. In the future, the formulae of faith will contribute to the Credo of the Church. 